\title{
Heterosis for Cured Leaf Yield in FCV (Flue-Cured Virginia) Tobacco (Nicotiana tabacum L.)
}

\author{
Megha Ganachari*, H.D. Mohan Kumar, B.M. Dushyantha Kumar, \\ S.P. Nataraju and H. Ravindra
}

Department of Genetics and Plant Breeding, College of Agriculture, Shivamogga

University of Agricultural and Horticultural Sciences, Shivamogga-577225, Karnataka, India

*Corresponding author

\section{A B S T R A C T}

\section{Keywords}

Analysis of variance, Commercial Check, FCV (Flue-Cured Virginia) tobacco, Heterosis and Variability

Article Info

Accepted:

15 July 2018

Available Online:

10 August 2018
The investigation was conducted to assess the heterosis in respect to leaf yield and its component characters through $6 \times 6$ diallel mating design involving thirty hybrids and six parents in FCV tobacco during kharif 2016 at ZAHRS (Zonal Agricultural and Horticultural Research Station), College of Agriculture Shivamogga. The analysis of variance indicated significant amount of variability among genotypes for sixteen quantitative characters studied except for the characters like number of leaves per plant, reducing sugar and nicotine content. Heterosis was recorded for leaf yield and its component characters and the study on standard heterosis revealed that five hybrids viz., 6 × 1, 3 x 1,2 x 1, 4 × 1 and 6 x 2 exhibited significant positive heterosis for cured leaf yield over best commercial check Kanchan.

\section{Introduction}

Tobacco (Nicotiana tabacum L.) is one of the most important non-edible commercial crop in India. It is one of the important commercial crop of national importance after sugarcane and cotton. It has been playing a prominent role in the development of national economy. Tobacco is commonly called as 'The Golden leaf' and is a member of Solanaceae family and belongs to genus Nicotiana. It is selfpollinated allopolyploid species. It is an amphidiploids $(2 \mathrm{n}=48)$ of Nicotiana sylvestris $(2 n=24)$ and Nicotiana tomentosa $(2 n=24)$, the wild progenitor species (Gerstel, 1960 and Gerstel, 1963) and are believed to be originated in tropical America (Akehurst, 1981). The quality of tobacco produced in Karnataka light soils (KLS) is on par with the best in the world and is in great demand for export purpose but in Karnataka yield levels of FCV tobacco are lower than the national average. Due to several fold increase in the cost of inputs and labour wages, farmers are 
not able to realize higher profit. The genetic potential of the present cultivated varieties has stagnated at $2000 \mathrm{~kg} / \mathrm{ha}$. Hence, it is desirable to enhance the genetic yield potential of the varieties up to $3000 \mathrm{~kg} / \mathrm{ha}$ through genetic improvement of the crop. Tobacco is an excellent source of phyto-chemicals viz., solanesol, nicotine, edible proteins (green leaf), tobacco seed oil and organic acids (malic and citric) which have pharmaceutical, agricultural and industrial uses. Tobacco produces nicotine sulphate which is used as an insecticide.

To enhance the present yield levels, it is essential a systemic varietal improvement through hybridization and exploitation of generated variability through recombination breeding. To achieve this, heterosis breeding is one of the tools which can be effectively used to improve yield. It is necessary to have detailed information about the desirable parental combination in any breeding programme that can involve a high degree of heterotic response. Therefore, heterotic studies can provide the basis for the exploitation of valuable hybrid combinations in future breeding programs. Top-cross, poly-cross and diallel crossing methods are used for the assessment of variability, combining ability and heterosis. Further, predicting the magnitude and frequency of heterotic hybrids assumes greater importance.

\section{Materials and Methods}

The present investigation on heterosis in tobacco (Nicotiana tabacum L.) was carried out during kharif season 2016. The experiment on heterosis was conducted in the experimental plot, College of Agriculture, ZAHRS (Zonal Agricultural and Horticultural Research Station), University of Agricultural and Horticultural Sciences, Shivamogga, Karanataka. Shivamogga comes under Southern transition agro climatic zone of Karnataka, (Zone number-7). Geographically,
Shivamogga is situated between $13027^{\prime}$ to 140 39' latitude and 740 37' E longitude with an altitude of $650 \mathrm{~m}$ above the MSL. A total rainfall of $1232.8 \mathrm{~mm}$ was received during the year of investigation.

The experimental material for study comprised of thirty $\mathrm{F}_{1}$ populations and their six parents (Bhavya, FCV- Special, Sahyadri, Kanchan, Tobios-6 and FCH-222), where Kanchan is used as a Standard check. These materials were used for genetic analysis of leaf yield and its component traits in FCV tobacco. Seedlings were grown in the nursery on the raised seed beds. The seedlings of $F_{1}$ hybrids and their parents in rows of $6 \mathrm{~m}$ length with spacing of $90 \times 60 \mathrm{~cm}$ were planted in a Simple Lattice Design (SLD) with three replications, during kharif 2016. Crop was raised as per the recommended package of practices. Observations recorded were Days to 50 per cent flowering, Days to maturity, Plant height $(\mathrm{cm})$, Chlorophyll content, Stem girth $(\mathrm{mm})$, Internodal distance $(\mathrm{cm})$, Number of leaves per plant, Specific leaf weight $\left(\mathrm{mg} / \mathrm{cm}^{2}\right)$, Leaf length $(\mathrm{cm})$, Leaf width $(\mathrm{cm})$, Leaf area per plant $\left(\mathrm{dm}^{2}\right)$, Green leaf yield (q/ha), Cured leaf yield ( $q / h a)$, Top grade equivalent (q/ha), Reducing sugar $(\%)$ and Nicotine content (\%).

The mean of all the replications for each parents, hybrids and check for each of the characters was computed and used in estimation of heterosis. Heterosis was calculated as the percentage increase or decrease of mean $F_{1}$ performance $\left(F_{1}\right)$ over the means of mid parent (MP), the better parent (BP) and the standard check (SC) were estimated by using formula by Turner (1953) and Hays et al.,(1955).

\section{Results and Discussion}

Heterosis breeding is an important genetic tool that can facilitate yield enhancement and helps 
to enrich many other desirable quantitative and qualitative traits in crops (Srivastava, 2000). It is now a well established fact that heterosis occurs in the hybrids when the most appropriate and compatible combinations of parents are involved.

In Analysis of variance (ANOVA), the variance due to genotypes (crosses and parents) was highly significant for all the traits except for number of leaves per plant, reducing sugar and nicotine content. This indicates the presence of variability among genotypes. Parents differed significantly among themselves for all the characters except for days to 50 per cent flowering, chlorophyll content, specific leaf weight, stem girth, number of leaves per plant, leaf breadth and nicotine content. The variance due to crosses was significant for all the characters except internodal distance, number of leaves per plant, reducing sugar and nicotine content. The variance due to parents vs. crosses was found to be significant for all the characters except for days to 50 per cent flowering, specific leaf weight, number of leaves per plant, reducing sugar and nicotine content.

The variance due to direct crosses $\left(\mathrm{F}_{1}\right)$ was found to be significant for all the characters except for internodal distance, number of leaves per plant, reducing sugar and nicotine content. The variance due to reciprocal crosses $\left(\mathrm{rF}_{1}\right)$ was found to be significant for all the characters except for internodal distance, number of leaves per plant, leaf area, green leaf yield, cured leaf yield, top grade equivalent (TGE) reducing sugar and nicotine content. The variance due to $F_{1}$ vs. reciprocals was found to be significant for all the characters except for chlorophyll content, specific leaf weight, stem girth, internodal distance, leaf length, leaf breadth, leaf area, reducing sugar and nicotine content (Table 1).

The significance variation among parents, among crosses, among $\mathrm{F}_{1}$ 's and among $\mathrm{rF}_{1}$ 's all indicate potential genetic differences among parents chosen and their prepotency. The two single degree of freedom comparisons - $\mathrm{F}_{1}$ 's vs. $\mathrm{rF}_{1}$ 's and parents vs. crosses correspondingly signify the presence of considerable reciprocal differences and heterosis in resultant hybrid progenies.

Positive heterosis is desirable for the character viz., Number of leaves per plant because it has high positive correlation with yield. The highest number of leaves was recorded by the hybrid 1 x 4 followed by $2 \times 5,1 \times 6,1 \times 3$ and $2 \times 1$ and $3 \times 1$. Highest significant positive heterosis was recorded in the cross 1 x 4 for number of leaves per plant mid parent, over better parent and over standard check viz., Kanchan (Table 3). Number of leaves par plant is one of the most important traits which directly contribute towards yield and heterosis in positive direction. Therefore plants with more number of leaves should be preferred to get higher yield.

Marani and Sachs (1966), Chen (1976), Aleksoska and Aleksoski. (2012), Patel et al., (2012a) and Ramachandra et al., (2015), reported positive mid-parent, better parent and standard heterosis for number of leaves per plant. Prasanna Simha Rao et al., (1990) reported negative better parent heterosis for number of leaves per plant.

Leaf area is also one of the important yield contributing traits in FCV tobacco. Positive heterosis is desirable for leaf area because leaf area has direct correlation with yield. But, only few are observed for positive heterosis over mid parent, better parent and over standard check (Kanchan).

Based on the top ranking crosses for leaf area are $2 \times 5,3 \times 1,2 \times 3,4 \times 5$ and 4 × 6 (Table $3)$. Leaf area is a trait which should be given more importance while selecting for cured leaf yield as it directly contribute to yield. 
Table.1 Analysis of variance (mean sum of squares) for sixteen traits in FCV Tobacco of Diallel analysis

\begin{tabular}{|c|c|c|c|c|c|c|c|c|c|c|c|}
\hline \multirow[t]{2}{*}{$\begin{array}{l}\text { Sl. } \\
\text { No. }\end{array}$} & Character & Replicates & Genotypes & Parents & $\begin{array}{l}\text { Hybrids } \\
\text { (Crosses) }\end{array}$ & $\begin{array}{c}\text { Parents Vs. } \\
\text { Hybrids }\end{array}$ & $\mathrm{F}_{1}$ 's & Reciprocals & $\begin{array}{c}\mathrm{F}_{1} \mathrm{Vs} \\
\text { Reciprocals }\end{array}$ & Error & Total \\
\hline & Degrees of freedom & 2 & 35 & 5 & 29 & 1 & 14 & 14 & 1 & 70 & 107 \\
\hline 1 & Days to 50 per cent flowering & 49.257 & $181.927 * *$ & 17.892 & $212.862 * *$ & 104.985 & $238.532 * *$ & $189.004 * *$ & $187.489 *$ & 40.663 & 87.032 \\
\hline 2 & Days to maturity & 38.535 & $500.512 * *$ & $73.456 * *$ & $560.583 * *$ & $893.719 * *$ & $435.719 * *$ & $502.133 * *$ & $3124.645^{* *}$ & 15.813 & 174.784 \\
\hline 3 & Plant height $(\mathrm{cm})$ & 22.088 & $719.527 * *$ & $891.266 * *$ & $637.994 * *$ & $2225.28 * *$ & $526.241 * *$ & $790.340 * *$ & $69.696 * *$ & 7.947 & 240.971 \\
\hline 4 & Chlorophyll content & 2.441 & $7.258 * *$ & 4.357 & $5.722 * *$ & $66.318 * *$ & $7.587 * *$ & $3.780 *$ & 6.801 & 2.024 & 3.744 \\
\hline 5 & Specific leaf weight $\left(\mathrm{mg} / \mathrm{cm}^{2}\right)$ & 1.986 & $1.193 * *$ & 0.443 & $1.346 * *$ & 0.461 & $1.731 * *$ & $0.990 * *$ & 0.996 & 0.419 & 0.702 \\
\hline 6 & Stem girth $(\mathrm{mm})$ & 1.662 & $5.354 * *$ & 0.226 & $5.500 * *$ & $26.757 * *$ & $7.047 * *$ & $4.346 * *$ & 0.001 & 0.782 & 2.294 \\
\hline 7 & Internodal distance $(\mathrm{cm})$ & 0.048 & $1.4550 * *$ & $7.1603 * *$ & 0.191 & $9.605^{* *}$ & 0.143 & 0.191 & 0.857 & 0.369 & 0.719 \\
\hline 8 & Number of leaves/plant & 0.894 & 1.521 & 1.005 & 1.653 & 0.285 & 2.125 & 0.787 & $7.168^{*}$ & 1.333 & 1.386 \\
\hline 9 & Leaf length $(\mathrm{cm})$ & 5.608 & $26.599 * *$ & $30.128 * *$ & $24.420 * *$ & $72.161 * *$ & $32.712 * *$ & $17.597 *$ & 3.844 & 7.594 & 13.774 \\
\hline 10 & Leaf breadth $(\mathrm{cm})$ & 0.863 & $9.866 * *$ & 2.336 & $11.001 * *$ & $14.603 *$ & $17.259 * *$ & $4.924 *$ & 8.464 & 2.135 & 4.640 \\
\hline 11 & Leaf area $\left(\mathrm{dm}^{2}\right)$ & 7535.06 & $32638.20 * *$ & $43736.31 *$ & $28874.60 *$ & $8629.18 *$ & $44313.12 * *$ & 15471.41 & 379.99 & 15840.42 & 21179.78 \\
\hline 12 & Green leaf yield (q/ha) & 6652.66 & $73813.75 * *$ & $131079.60 * *$ & $40089.34 *$ & $765492.20 * *$ & $43874.70^{*}$ & 26831.54 & $172703.40 * *$ & 21492.26 & 38329.39 \\
\hline 13 & Cured leaf yield (q/ha) & 91.868 & $1233.68 * *$ & $1887.54 * *$ & $808.72 *$ & $10288.24^{* *}$ & $999.03 *$ & 487.91 & $2635.85^{* *}$ & 307.03 & 606.12 \\
\hline 14 & Top grade equivalent (q/ha) & 33.07 & $444.12 * *$ & $679.51 * *$ & $291.14 *$ & $3703.76^{* *}$ & $359.65 *$ & 175.64 & $948.90 * *$ & 110.53 & 218.20 \\
\hline 15 & Reducing sugar (\%) & 2.013 & 2.476 & $8.831 * *$ & 1.418 & 1.404 & 1.330 & 1.559 & 0.680 & 2.137 & 2.246 \\
\hline 16 & Nicotine content $(\%)$ & 0.163 & 0.010 & 0.009 & 0.011 & 0.001 & 0.010 & 0.012 & 0.001 & 0.010 & 0.013 \\
\hline
\end{tabular}

* - Significance at 5 per cent level, ** - Significant at 1 per cent level 
Table.2 Number of crosses showing significant heterosis level with respect to directions and ranges

\begin{tabular}{|c|c|c|c|c|c|c|c|c|c|c|}
\hline \multirow{2}{*}{$\begin{array}{l}\text { Sl. } \\
\text { No. }\end{array}$} & \multirow[t]{2}{*}{ Characters } & \multicolumn{3}{|c|}{ Mid-parent heterosis } & \multicolumn{3}{|c|}{ Better parent heterosis } & \multicolumn{3}{|c|}{ Standard heterosis } \\
\hline & & Positive & Negative & Range & Positive & Negative & Range & Positive & Negative & Range \\
\hline 1 & Days to 50 per cent flowering & 5 & 15 & -16.38 to 12.43 & 5 & 17 & -16.74 to 10.16 & 6 & 8 & -12.37 to 14.91 \\
\hline 2 & Days to maturity & 7 & 19 & -15.59 to 13.03 & 5 & 20 & -17.32 to 10.26 & 7 & 18 & -15.69 to 10.12 \\
\hline 3 & Plant height (cm) & 10 & 17 & -30.05 to 12.10 & 3 & 25 & -31.90 to 2.19 & 27 & 2 & -10.81 to 28.01 \\
\hline 4 & Chlorophyll content & 2 & 23 & -23.21 to 9.61 & 1 & 25 & -29.33 to 6.09 & 2 & 19 & -26.66 to 13.37 \\
\hline 5 & Specific leaf weight $\left(\mathrm{mg} / \mathrm{cm}^{2}\right)$ & 8 & 8 & -28.01 to 23.30 & 3 & 13 & -31.30 to 17.78 & 7 & 14 & -31.30 to 15.7 \\
\hline 6 & Stem girth (mm) & 4 & 13 & -17.64 to 4.01 & 5 & 14 & -17.68 to 5.85 & 2 & 14 & -15.38 to 6.78 \\
\hline 7 & Internodal distance $(\mathrm{cm})$ & 1 & 13 & -44.40 to 6.13 & 1 & 15 & -22.93 to 10.05 & 0 & 23 & -27.45 to -0.29 \\
\hline 8 & Number of leaves/ plant & 15 & 3 & -8.76 to 20.00 & 11 & 8 & -12.81 to 16.49 & 19 & 0 & -0.56 to 23.72 \\
\hline 9 & Leaf length (cm) & 7 & 11 & -22.66 to 5.28 & 2 & 17 & -26.23 to 1.11 & 26 & 2 & -14.32 to 15.08 \\
\hline 10 & Leaf breadth $(\mathrm{cm})$ & 11 & 10 & -23.10 to 7.09 & 11 & 11 & -26.35 to 5.49 & 12 & 8 & -20.15 to 7.90 \\
\hline 11 & Leaf area $\left(\mathrm{dm}^{2}\right)$ & 9 & 14 & -27.11 to 17.53 & 3 & 19 & -33.82 to 9.22 & 25 & 2 & -11.28 to 37.85 \\
\hline 12 & Green leaf yield (q/ha) & 26 & 1 & -9.13 to 79.69 & 20 & 2 & -10.90 to 61.76 & 10 & 2 & -34.17 to 15.77 \\
\hline 14 & Top grade equivalent (q/ha) & 25 & 2 & -12.24 to 79.69 & 20 & 3 & -20.99 to 61.76 & 10 & 4 & -45.14 to 15.77 \\
\hline 15 & Reducing sugar (\%) & 13 & 14 & -21.01 to 17.72 & 6 & 19 & -25.67 to 10.36 & 30 & 0 & 6.84 to 30.38 \\
\hline 16 & Nicotine content $(\%)$ & 9 & 0 & -11.04 to 10.75 & 6 & 0 & -14.62 to 10.39 & 11 & 0 & -10.45 to 11.76 \\
\hline
\end{tabular}


Table.3 Promising hybrids with per se performance and heterosis for sixteen characters in FCV tobacco

\begin{tabular}{|c|c|c|c|c|c|c|c|}
\hline \multirow[t]{2}{*}{ Characters } & \multirow{2}{*}{$\begin{array}{l}\text { Desirable } \\
\text { crosses }\end{array}$} & \multicolumn{3}{|c|}{ Perse } & \multicolumn{3}{|c|}{ Heterosis } \\
\hline & & Female & Male & $\mathbf{F}_{1}$ & MP & $\mathbf{B P}$ & SC \\
\hline \multirow{6}{*}{$\begin{array}{l}\text { Days to } 50 \text { per cent } \\
\text { flowering }\end{array}$} & $1 \times 6$ & 129.8 & 125.40 & 108.06 & $-15.31 * *$ & $-16.74 * *$ & $-12.37 * *$ \\
\hline & $2 \times 1$ & 128.66 & 129.80 & 108.06 & $-16.38 * *$ & $-16.74 * *$ & $-12.37 * *$ \\
\hline & $3 \times 6$ & 125.60 & 125.40 & 113.70 & $-9.40 * *$ & $-9.47 * *$ & $-7.81 * *$ \\
\hline & $1 \times 2$ & 129.80 & 128.66 & 114.50 & $-11.40 * *$ & $-11.79 * *$ & $-7.16 * *$ \\
\hline & $2 \times 4$ & 128.66 & 123.33 & 114.76 & $-8.92 * *$ & $-10.80 * *$ & $-6.94 * *$ \\
\hline & $2 \times 6$ & 128.66 & 125.40 & 117.10 & $-7.82 * *$ & $-8.99 * *$ & $-5.05 * *$ \\
\hline \multirow[t]{5}{*}{ Days to maturity } & $2 \times 6$ & 172.40 & 163.80 & 145.40 & $-13.50 * *$ & $-15.66 * *$ & $-15.69 * *$ \\
\hline & $1 \times 5$ & 172.06 & 179.40 & 148.33 & $-15.59 * *$ & $-17.32 * *$ & $-13.99 * *$ \\
\hline & $3 \times 6$ & 172.26 & 163.80 & 148.46 & $-11.64 * *$ & $-13.82 * *$ & $-13.91 * *$ \\
\hline & $2 \times 4$ & 172.40 & 172.46 & 148.80 & $-13.71 * *$ & $-13.72 * *$ & $-13.72 * *$ \\
\hline & $4 \times 3$ & 172.46 & 172.26 & 148.83 & $-13.68 * *$ & $-13.70 * *$ & $-13.70 * *$ \\
\hline \multirow{5}{*}{ Plant height (cm) } & $6 \times 3$ & 188.40 & 187.93 & 192.53 & $2.32 * *$ & $2.19 * *$ & $28.01 * *$ \\
\hline & $5 \times 6$ & 186.66 & 188.40 & 192.20 & $2.49 * *$ & $2.02 * *$ & $27.79 * *$ \\
\hline & $6 \times 1$ & 188.40 & 198.93 & 189.93 & -1.93 & $-4.52 * *$ & $26.28 * *$ \\
\hline & $4 \times 5$ & 150.40 & 186.66 & 188.93 & $12.10 * *$ & $1.21 * *$ & $25.62 * *$ \\
\hline & $6 \times 4$ & 188.40 & 150.40 & 186.60 & $10.15^{* *}$ & -0.96 & $24.06 * *$ \\
\hline \multirow[t]{5}{*}{ Chlorophyll content } & $4 \times 5$ & 16.80 & 17.95 & 19.04 & $9.61 * *$ & $6.09 * *$ & $13.37 * *$ \\
\hline & $1 \times 4$ & 17.40 & 16.80 & 17.01 & -0.53 & -2.26 & $1.26 * *$ \\
\hline & $4 \times 3$ & 16.80 & 14.55 & 16.52 & $5.38 * *$ & -1.67 & -1.66 \\
\hline & $2 \times 4$ & 17.20 & 16.80 & 16.20 & -4.72 & -5.85 & -3.57 \\
\hline & $1 \times 5$ & 17.40 & 17.95 & 16.08 & $-9.05^{*}$ & $-10.43 * *$ & -4.28 \\
\hline \multirow{5}{*}{$\begin{array}{l}\text { Specific leaf weight } \\
\left(\mathrm{mg} / \mathrm{cm}^{2}\right)\end{array}$} & $2 \times 6$ & 5.87 & 5.08 & 6.58 & $23.30 * *$ & $17.78 * *$ & $15.70 * *$ \\
\hline & $1 \times 5$ & 5.99 & 5.17 & 6.14 & $10.19 * *$ & 2.62 & $8.08 * *$ \\
\hline & $1 \times 6$ & 5.99 & 5.08 & 6.06 & $9.52 *$ & 1.26 & $6.65 * *$ \\
\hline & $2 \times 1$ & 5.87 & 5.87 & 6.01 & 3.77 & 0.28 & $5.62 * *$ \\
\hline & $3 \times 1$ & 5.04 & 5.04 & 5.99 & $8.61 * *$ & 0.06 & $5.39 * *$ \\
\hline \multirow[t]{5}{*}{ Stem girth $(\mathbf{m m})$} & $3 \times 6$ & 26.09 & 26.08 & 27.13 & $4.01 * *$ & $3.98 * *$ & $6.78 * *$ \\
\hline & $3 \times 4$ & 26.09 & 25.41 & 26.31 & $2.16^{* *}$ & $0.82 * *$ & $3.54 *$ \\
\hline & $1 \times 2$ & 25.86 & 26.11 & 26.22 & $0.89 * *$ & $0.40 * *$ & 3.19 \\
\hline & $5 \times 4$ & 26.06 & 25.41 & 26.13 & $1.56^{* *}$ & $0.29 * *$ & 2.86 \\
\hline & $6 \times 3$ & 26.08 & 26.09 & 25.85 & -0.91 & -0.94 & 1.73 \\
\hline \multirow{5}{*}{$\begin{array}{l}\text { Internodal distance } \\
(\mathbf{c m})\end{array}$} & $6 \times 4$ & 4.27 & 4.54 & 3.29 & $-15.70 *$ & -22.93 & $-27.45 * *$ \\
\hline & $6 \times 3$ & 4.27 & 7.93 & 3.39 & $-44.40 * *$ & $-57.23 * *$ & $-25.25^{* *}$ \\
\hline & $6 \times 5$ & 4.27 & 4.14 & 3.77 & $-10.37 *$ & -11.70 & -16.88 \\
\hline & $3 \times 6$ & 7.93 & 4.27 & 3.80 & $-37.74 * *$ & $-52.10 * *$ & -16.29 \\
\hline & $1 \times 3$ & 3.98 & 7.93 & 3.83 & $-35.65 * *$ & $-51.68 * *$ & $-15.56 * *$ \\
\hline \multirow{6}{*}{$\begin{array}{c}\text { Number of leaves per } \\
\text { plant }\end{array}$} & $1 \times 4$ & 12.53 & 11.80 & 14.60 & $20.00 * *$ & $16.49 * *$ & $23.72 * *$ \\
\hline & $2 \times 5$ & 12.2 & 12.33 & 14.20 & $15.76^{* *}$ & $15.14^{* *}$ & $20.33^{*}$ \\
\hline & $1 \times 6$ & 12.53 & 13.53 & 13.73 & $5.37 * *$ & $1.48^{* *}$ & $16.38^{* *}$ \\
\hline & $1 \times 3$ & 12.53 & 12.46 & 13.33 & $6.67 * *$ & $6.38 * *$ & $12.99 * *$ \\
\hline & $2 \times 1$ & 12.20 & 12.53 & 13.33 & $7.82 * *$ & $6.38 * *$ & $12.99 * *$ \\
\hline & $3 \times 1$ & 12.46 & 12.53 & 13.26 & $6.13^{* *}$ & $5.85 * *$ & $12.42 * *$ \\
\hline
\end{tabular}


Similar results for leaf area was obtained by Wilkinson et al., (1994), Kher et al., (2001a), Gixhari and Sulovari (2010) and Ramachandra et al., (2015) Therefore this cross may be prove to be useful for obtaining plants with higher leaf area per plant it is most desirable in tobacco.

Total Cured leaf yield which is the important parameter and majority of the researchers have reported significant positive heterotic effects for cured leaf yield. The highest cured leaf yield exhibited by cross $6 \times 1$ followed by $3 \times 1,2 \times 1,4 \times 1$ and $6 \times 2$. The maximum and positively significant heterosis was observed in the cross $2 \times 1$ over mid parent and over the better parent, whereas the cross 6 $\mathrm{x} 1 \mathrm{had}$ maximum and positively significant heterosis over standard check (Table 3). Similar results reported by Ramachandra (2004) and Aleksoska and Aleksoski (2012).

Positive heterosis is also desirable for the character like Top Grade Equivalent (TGE). The highest top grade equivalent exhibited by the cross $6 \times 1$ followed by $3 \times 1,2 \times 1,4 \times 1$ and $6 \times 2$. The maximum and positively significant heterosis was observed in the cross $2 \times 1$ over mid parent and over the better parent, whereas the cross $6 \times 1$ had maximum and positively significant heterosis over standard check

Negative heterosis is desirable for the percent Nicotine content in leaves. But, no crosses for negative heterosis over mid parent, better parent and over standard check was found. The minimum per se performance was observed in the cross $1 \times 3$ followed by $1 \times 2$, $5 \times 3,5 \times 1$ and $2 \times 6$. Darkanbaev et al., (1962) and Ramachandra et al., (2015) recorded positive mid parent better parent and standard heterosis

Number of crosses showing significant heterosis level with respect to directions and ranges is shown in Table 2 and promising hybrids with perse performance and heterosis for sixteen characters in FCV tobacco is shown in Table 3.

\section{References}

AKEHURST, B.C., 1981, Tobacco. New York: Longman.

ALEKSOSKA, A. K. AND ALEKSOSKI, J., 2012, Investigations of combining abilities in diallel set of varieties belonging to several tobacco types. Agric. conspec. sci., 77(4): 203-206.

CHEN, S. Y., 1976, Diallel analysis and phenotypic recurrent selection for high yield and low alkaloid content in burley tobacco (Nicotiana tabacum L.). Dissertation - Abstracts International., 36(7): 315-513.

DARKANBAEV, T. B., LUKPANOOV, Z. L. AND KALEKENOV, Z., 1962, Physiological and biochemical characteristics of a heterotic tobacco form physiologia. Plantae., 9: 60-68.

GERSTEL, D. U., 1960, Segregation in new allopolyploids of Nicotiana. I. Comparison of 6x (N. tabacum x $N$. tomentosiformis) and 6x (N. tabacum x N. otophora). Gen., 45: 1723-1734.

GERSTEL, D. U., 1963, Segregation in new allopolyploids of Nicotiana. II. Discordant ratios from individual loci in 6x ( $N$. tabacum $\mathrm{x} N$. sylvestris). Gen, 48: 677-689.

GIXHARI, B. AND SULOVARI, H., 2010, Nature of inheritance and heterosis estimated on some morphological quantitative characters that influence the tobacco yield. J. Bio., 18: 46-50.

HAYS, H. K., IMMER, F. R. AND SMITH, B. C., 1955, Meth. Pl. Bred., II McGraw Hills. New York.

KHER, H. R., PATHAK, H. C., MAKWANA, M. G. AND PATEL, J. M., 2001a, Combining ability studies 
for yield and yield components in bidi tobacco. Nicotiana tabacum L. over diverse cytoplasm. Tob. Res., 27: 134139.

MARANI, A. AND SACHS, Y., 1966, Heterosis and combining ability in a diallel cross among nine varieties of oriental tobacco. Crop Sci., 6: 19-22.

PATEL, J. N., PATEL, A. D., SUDESHNA CHAKRABOTY AND SASIDHARAN, N. 2012a. Heterosis and relative heterosis in tobacco Nicotiana tabaccum L.). Int. J. Pl. Animal Environ. Sci., 2: 270-275.

PRASANNA SIMHA RAO, S. B., ILYAR AHMED, M. AND SUBRAMANYAM, G.S.V., 1990, Heterosis and combining ability in FCV tobacco (Nicotiana tabacum L.). Tob. Res., 16(1): 9-14.

RAMACHANDRA， R. K., 2004，Genetic analysis of leaf yield and chemical composition in bidi tobacco (Nicotiana tabacum L.). Ph.D thesis, Univ. Agric. Sci., Dharwad, 150pp.

RAMACHANDRA, R. K., NAGAPPA B. H AND ANJENAYA REDDY B. 2015. Heterosis studieson yield and quality parameters in bidi tobacco. J. Bio. Innov., 4(4): 126-134.

SRIVASTAVA, V. K., 2000. Indian J. Hort., 21: $165-9$

TURNER, T. H., 1953, A study of heterosis in upland cotton, yield of hybrids compared with varieties. Agr. J., 45: 484-486.

WILKINSON, C. A., JONES, J. L. AND TILSON, W. M., 1994, Diallel analysis of crosses among virginia fire-cured tobacco cultivars. Tob. Sci., 38: 21-24.

\section{How to cite this article:}

Megha Ganachari, H.D. Mohan Kumar, B.M. Dushyantha Kumar, S.P. Nataraju and H. Ravindra. 2018. Heterosis for Cured Leaf Yield in FCV (Flue-Cured Virginia) Tobacco (Nicotiana tabacum L.). Int.J.Curr.Microbiol.App.Sci. 7(08): 2726-2733. doi: https://doi.org/10.20546/ijcmas.2018.708.285 